住居対象連続侵入窃盗事件における犯人属性の犯罪手ロによる予測

\author{
萩野谷俊平 1 , 花山愛子 ${ }^{2}$, 小野修一 3 ,

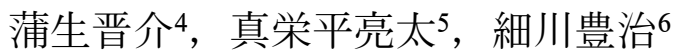 \\ 1栃木県警察本部刑事部科学捜査研究所 \\ 干320-8510 栃木県宇都宮市塙田 1 丁目 1 番20号 \\ 2 青森県警察本部刑事部科学捜査研究所 \\ 干030-0801＼cjkstart青森県青森市新町 2 丁目 3 番 1 号 \\ 3科学警察研究所 \\ 干277-0882 千葉県柏市柏の葉 6 丁目 3 番地 1 \\ 4愛媛県警察本部刑事部科学捜査研究所 \\ 干790-8573 愛媛県松山市南堀端町 2 番地 2 \\ 5 沖縄県警察本部刑事部科学捜査研究所 \\ 干900-0021 沖縄県那覇市泉㠃 1 丁目 2 番 2 号 \\ 6静岡県警察本部刑事部科学捜査研究所 \\ 干424-0055 静岡県静岡市清水区吉川373番地 1
}

\title{
Predicting offender characteristics in serial house burglaries based on modus operandi
}

\author{
Shumpei Haginoya ${ }^{1}$, Aiko Hanayama ${ }^{2}$, Shuichi $\mathrm{Ono}^{3}$, Shinsuke Gamo ${ }^{4}$, \\ Ryota Maehira $^{5}$ and Toyoharu Hosokawa ${ }^{6}$ \\ ${ }^{1}$ Forensic Sci. Lab., Tochigi Pref. Police H.Q. \\ 1-1-20 Hanawada, Utsunomiya-shi, Tochigi 320-8510, Japan \\ ${ }^{2}$ Scientific Invest. Lab., Aomori Pref. Police H.Q. \\ 2-3-1 Shinmachi, Aomori-shi, Aomori 030-0801, Japan \\ ${ }^{3}$ National Research Institute of Police Science \\ 6-3-1 Kashiwanoha, Kashiwa-shi, Chiba 277-0882, Japan \\ ${ }^{4}$ Forensic Sci. Lab., Ehime Pref. Police H.Q. \\ 2-2 Minamihoribata-cho, Matsuyamashi, Ehime 790-8573, Japan \\ ${ }^{5}$ Criminal Invest. Lab., Okinawa Pref. Police H.Q. \\ 1-2-2 Izumizaki, Naha-shi, Okinawa 900-0021, Japan \\ ${ }^{6}$ Forensic Sci. Lab., Shizuoka Pref. Police H.Q. \\ 373-1 Kikkawa, Shimizu-ku, Shizuoka-shi, Shizuoka 424-0055, Japan
}

(Received 15 April 2013; accepted 4 October 2013)

The objective of this study was to identify patterns of modus operandi that would be effective for predicting offender characteristics. For this purpose, logistic regression models were developed based on offender characteristics (17 variables) 
and modus operandi (50 variables) related to burglaries of residences, by using a stepwise method. Useful models were selected by using the area under the ROC curve, and by improvements in prediction accuracy from the prior probability, based on the frequency of the category of each offender characteristic. Models containing the following four offender characteristics were selected as useful: age, presence of a co-offender, criminal history of house burglaries with no one home, and criminal history of house burglaries late at night. Burglary experiences and age emerged as common potential factors of modus operandi and offender characteristics. It is suggested that selected modus operandi could be utilized to predict offender characteristics.

Key words: Offender profiling, Burglary, Modus operandi, Offender characteristics, Logistic regression analysis

\section{緒 言}

犯罪者プロファイリングにおける犯人像推定

犯罪者プロファイリングは，実務の過程におい て, 事件リンク分析, 犯人像推定, 地理的プロファ イリングの 3 つの領域に大別される ${ }^{1)}$. 事件リンク 分析は，分析対象となる連続事件の中で同一犯人に よると考えられる事件を抽出する手法であり，この 分析で抽出された事件が犯人像推定および地理的プ ロファイリングの分析対象となる．犯人像推定で は, 犯人属性（年齢, 性別, 職業, 犯罪経歴など） を推定する方法として, 統計手法を用いる方法と, 事例分析による方法の 2 つが用いられる. 地理的プ ロファイリングでは，各事件現場の地理的情報から 犯人の活動拠点や次回の犯行が行われる場所に関す る分析が行われる.

これらの中でも犯人像推定は，犯罪捜査の実務に 携わる人々に犯罪者の分類や一般的特徵に関する情 報を提供することを目的として，犯罪者プロファイ リングの歴史初期から盛んに研究が行われている分 野であり ${ }^{2,3)}$, 日本に扮いても多くの基礎的な研究 が行われている ${ }^{4-9)}$. 犯罪者プロファイリングによ って推定された犯人像は, 浮上している容疑者リス 卜の優先順位付けや，犯人像之一致する犯罪経歴者 の抽出, 捜査員による聞き込みや警戒で不審者を発 見するための情報などに活用されることが多い。こ の手法が活用される事件は, 殺人, 強盗, 性犯罪, 窃盗など多様であり, なかでも侵入窃盗事件は, 犯
人と被害者の間に面識のないケースが多く，被害者 の人間関係から犯人を割り出すことができない場合 がほとんどであることから ${ }^{10)}$, 犯人像推定を活用で きるケースが多いと考えられる.

\section{窃盗犯捜査における犯人像推定の重要性}

日本の窃盗事件の捜査では，犯罪手口（犯行場 所，侵入方法，物色方法，目的物など）を活用した 手口捜査が長年行われており，その一環として，犯 人像推定も行われている11)。これは，窃盗犯捜査に おける犯人像推定の重要性を示していると言える. また，手口捜査における犯人像推定は捜査員の経験 に基づいて行われているため，科学的知見に基づい た犯罪者プロファイリングによる犯人像推定は，従 来の手口捜査をより強化し, 窃盗事件捜査に寄与す るものと考えられる.ささに，手口捜査では同種手 口の犯罪経歴者の検索が主たる目的となるが，犯罪 者プロファイリングの犯人像推定では，現状では十 分な知見は得られていないものの，犯人が犯罪経歴 のない初犯者である場合にも研究によって犯人像を 推定するモデルを構築できる可能性がある．同様 に，犯罪経歴の有無についても推定モデルを構築す ることで，分析対象事件に手口捜査を適用すべきか 否か，適用するのであれば，どのような罪種の犯罪 経歴者を抽出すべきかといった意思決定の支援も期 待できる.

現在の犯罪者プロファイリングによる犯人像推定の 限界

現在の犯罪者プロファイリングによる犯人像推定 
では，主として過去の類似事件における犯人属性の 記述統計的特徵から推定を行う方法や，多変量解析 などを用いて見いだされた類型，犯行テーマから犯 人属性の推定を行う方法が用いられている。侵入窃 盗における犯人像推定に関する研究は少ないが，犯 人の類型化を目的とした基礎研究として, 高村と徳 山による研究があげられる ${ }^{4,5)}$. 高村と徳山は，犯 人の動機的側面に着目し, 民家対象窃盗犯の犯人属 性や犯罪手口，取調べに関する項目について金銭動 機と性的動機を比較して，動機の違いによって犯人 特性が異なることを指摘し，さらに金銭動機で民家 に侵入する筇盗犯の犯人特性は性的動機の窃盗犯に 比べて多様性が大きいことを報告している4). そこ で高村と徳山は，金銭動機による民家対象窃盗犯の 犯罪行動と犯人属性を同時に数量化夏類で分析し， 見出した 4 つの群（初犯有職群, 少年群, 累犯広域 群, 累犯非広域群）について特徵的な犯罪行動・犯 人属性をあげている5).

しかしながら, 記述統計的特徵や類型, 犯行テー マによる犯人像推定には, 推定の過程に抢ける限界 が存在する．たとえば過去の類似事件から犯人属性 の記述統計的特徵を導く方法では, より推定に適し た事件を抽出するために特徵的な犯罪手口による類 似事件の絞り込久を行うが，その際に犯罪手口を選 択する基準は分析者の経験的知識に基づくものであ ることが多い。また，多变量解析などを用いて見い だされた類型や犯行テーマから犯人属性の推定を行 う方法では, 推定結果が数種類の類型や犯行テーマ に限定されてしまうとともに，犯行テーマに対応し て犯人属性を分類できることが非常にまれであるこ とが指摘されている(2). 加えて, 財津 ${ }^{13)}$ は, 類型や 犯行テーマによる犯人像推定の限界として，分析対 象事件の類型への分類が恣意的なものであること， 犯罪の一般的傾向を重視して抢り個々の事件の特異 な犯罪行動が不鮮明となること, 個々の犯人属性の 推定結果の妥当性を確率で表現できないことなどを あげている。したがって，これらの限界を克服する ためには，客観的な手法で犯人属性と関連がある犯 罪手口を選択し，それらの犯罪手口から直接犯人属 性を予測することが求められる.

\section{先行研究と本研究の目的}

犯罪手口の情報から犯人属性の予測を検討した研 究としては, Santtila et al. による研究があげられ る14). Santtila et al. は, 回帰モデルを用いて犯罪 手口から侵入容盗犯の犯人属性の予測を検討した結 果, 54の犯人属性のうち9つで回帰モデルによる推 定確率が要約統計による推定確率を上回ったことを 示しており，捜査での犯人像推定や新任の警察官へ の講義, 既知の窃盗犯のデータベースから容疑者リ ストを作成するシステムの構築に活用される可能性 を指摘している. しかし，この研究では85の犯罪手 口に主成分分析を適用して抽出した14の主成分を説 明変数として予測を行っており，Santtila et al.の 研究も犯罪手口の類型を介した間接的な推定である と言わざるを得ない，捜査の段階ですべての犯罪手 口が常に明確なわけではない実務の分析において は15)，これらの主成分得点を算出するために必要な 全ての犯罪手口に関する情報を收集することは難し い. 性犯罪16)や殺人17)を対象とした研究では, 犯行 現場で得られる情報を直接説明変数として犯人属性 を予測するモデルを作成しており，窃盗事件におい ても各犯人属性を予測するために重要な犯罪手口が 抽出され，それらの組久合わせによって直接予測す ることが可能であれば，犯罪手口に関する情報が不 完全であっても，犯人属性を予測できるケースは多 いと考えられる.

そこで本研究では，日本に抢ける住居を対象とす る連続侵入窃盗犯について, 犯人属性の予測に有用 な犯罪手口の組み合わせを検討することで, 捜査支 援活動により柔軟に活用できる犯人像推定の手法を 見出すことを目的とした。

\section{データ}

\section{方 法}

郊外に位置する5つの県において，2004年から 2010年までの間に， 5 ヶ所以上 ${ }^{1}$ の住居を対象とす る連続侵入窃盗事件に及んで検挙された 305 名に関 する事件資料を収集した ${ }^{2}$. 同じ犯人に複数の記録 がある場合，もっとも古い記録のみを使用した．複 数犯による事件の場合, 主犯（または実行犯）とし て記録されている 1 名の資料を収集した，分析に使 
Table 1 Offender characteristics used as the dependent variables.

\begin{tabular}{|c|c|c|c|}
\hline Variable & $\%$ & Variable & $\%$ \\
\hline $\begin{array}{l}\text { Offender age at the time of the first offense } \\
36 \text { or more }\end{array}$ & 49.8 & $\begin{array}{l}\text { Familiarity with the victimised area and/or } \\
\text { with the victim }\end{array}$ & \\
\hline Less than 36 & 50.2 & Familiarity with the victim & 6.9 \\
\hline Sex & & Familiarity with the area & 67.2 \\
\hline Male & 95.7 & Lack of familiarity with the victim and the area & 19.7 \\
\hline Female & 3.6 & $\begin{array}{l}\text { Criminal history of house burglaries (stealing } \\
\text { in one's absence) }\end{array}$ & \\
\hline Presence of co-offender & & With & 49.8 \\
\hline With & 20.0 & Without & 50.2 \\
\hline Employment status & 00.0 & $\begin{array}{l}\text { Criminal history of house burglaries (stealing } \\
\text { late at night) }\end{array}$ & \\
\hline Employed & 30.5 & With & 38.4 \\
\hline Unemployed & 69.5 & Without & 61.6 \\
\hline $\begin{array}{l}\text { Marital status } \\
\text { Married or Divorced }\end{array}$ & 38.7 & $\begin{array}{l}\text { Criminal history of house burglaries (stealing } \\
\text { while one's at home) }\end{array}$ & \\
\hline Unmarried & 61.3 & With & 19.3 \\
\hline Residential status & & Without & 80.7 \\
\hline With a permanent address & 65.2 & Criminal history of burglaries other than house & \\
\hline No address & 33.4 & With & 42.3 \\
\hline Education & & Without & 57.7 \\
\hline High school graduation or more & 34.1 & Criminal history of theft through non-break- & \\
\hline $\begin{array}{l}\text { Some high school, junior high school gradu- } \\
\text { ation, or less }\end{array}$ & 60.3 & $\begin{array}{l}\text { ing and non-entering } \\
\text { With }\end{array}$ & 58.0 \\
\hline Mental problem & & Without & 42.0 \\
\hline With & 4.6 & Criminal history other than theft & \\
\hline \multirow[t]{2}{*}{ Without } & 95.4 & With & 33.4 \\
\hline & & Without & 66.6 \\
\hline
\end{tabular}

The data include missing values.

用する変数は, Santtila et al. ${ }^{14)}$ および高村と徳 山年)の研究を参考として, 犯人属性に関する17変 数（Table 1）と犯罪手口に関する50変数（Table 2) を，0末たは 1 の 2 值にコーディングした．犯行時 年齢（記録上の第 1 犯行時の年齢）はより細かく分 けることもできるが，細分化することで判別的中率

\footnotetext{
${ }^{1}$ 橫田・渡辺 (1998) ${ }^{18)}$ による侵入穷盗の手口の反復性に関す る研究では, 過去の犯行回数が多いほど, それ以降に行う犯行 では過去に選択したことのある手口を選択する可能性が高くな り, 被疑者が犯行で選択する手口の種類が特定化することが示 されている, また, 橫田 ·渡辺 (1998) は, 手口から上手く被 疑者を絞り込むための目安として, 犯行回数が 5 回以上である ことをあげている．さらに，犯人像推定と並行して行われると 考えられる地理的プロファイリングを実施する目安として, 最 低 5 力所の犯行地点情報を収集できることが三本 (2006) ${ }^{19)}$ によ って提示されていることも考慮して, 本研究では, 5 カ所以上の 事件を対象とした。

2参考屯でに同時期における同種事件の半数近く（46～67\%） は未検挙であることを記しておく.
}

（全サンプル中で正しく判別されたサンプルの割合） が大きく低下することが考えられるため，本研究で は財津が連続強姦事件の犯行間隔日数を予測する際 に使用した方法にしたがい20)，中央值で 2 分割して 再コーディングした年齢（36歳以上，36歳未満）を 用いて実用可能なモデルを探索した。犯行対象（現 場の住人，現場周辺の地理）についての知識の程度 は，「被害者に関する知識あり」「現場付近の地理的 環境に関する知識あり」「被害者・現場に関する知 識なし」の 3 つのカテゴリがあるため, 各カテゴリ をダミ一変数に置き換えて使用した.

本研究で用いたデータには, 潜在的なバイアスが 存在する，たとえば，データは科学的研究のためで はなく犯罪捜査に活用するために作成された資料に 基づいているため，資料に記録されていない犯罪手 
Table 2 Modus operandi used as the independent variables.

\begin{tabular}{|c|c|c|c|}
\hline Variable & $\%$ & Variable & $\%$ \\
\hline Time of crime & & Peculiarity of escape & \\
\hline Daytime & 64.6 & Esceped from exit other than the place of entry & 33.4 \\
\hline Evening & 30.5 & Esceped from the place of entry & 45.6 \\
\hline Late at night & 31.1 & Exit closed & 48.2 \\
\hline Circumstance of Victimized area & & Exit open & 7.5 \\
\hline Near station & 10.8 & Abandoned tools and stolen goods on the & 220 \\
\hline On or near main thoroughfare & 28.9 & way to escape & 22.0 \\
\hline On alley & 86.2 & Stolen items & \\
\hline Residential streets & 77.7 & Cash & 95.4 \\
\hline Fishing and farming villages & 37.0 & Credit cards, passbooks and seals & 30.2 \\
\hline Tools for a crime & & Coupons and tickets & 31.8 \\
\hline Tool brought to scene and used & 72.8 & Jewellery & 37.7 \\
\hline Tool from scene used & 14.4 & Watches & 26.9 \\
\hline Peculiarity of entry & & Cameras & 15.4 \\
\hline Entry through a door & 59.3 & PCs & 8.2 \\
\hline Entry through a window & 87.2 & Audio-visual equipment & 9.8 \\
\hline Entry through a unlocked entrance & 76.7 & Small electrical items & 8.9 \\
\hline Forced entry & 52.8 & Bags & 42.0 \\
\hline One's shoes off & 37.0 & Clothes & 12.8 \\
\hline With one's shoes on & 57.0 & Lingerie & 14.4 \\
\hline Peculiarity of ransacking & & Food and cigarettes & 15.7 \\
\hline Furniture searched & 87.9 & Toys and games & 19.3 \\
\hline Bag searched & 40.7 & Strongboxes & 13.8 \\
\hline Strongbox searched & 13.8 & Credit cards used & 9.5 \\
\hline Haphazardly search & 35.1 & Other peculiarity & \\
\hline Slightly search & 47.2 & Spree & 54.4 \\
\hline Tidy search & 40.7 & Repeat burglary same house & 29.8 \\
\hline Untidy search & 19.7 & Use of stolen bicycles & 12.1 \\
\hline Cash with wallet stolen & 39.0 & & \\
\hline Took money out of wallet & 31.5 & & \\
\hline Forensically care & 66.2 & & \\
\hline
\end{tabular}

口についても，実際には犯行で行われている可能性 がある ${ }^{21,22)}$ 。た，事件資料は警察官によって作成 されているため，評定者間信頼性は評価できない． しかし，このようなデータに対して犯罪手口による 犯人属性の予測を検証する場合においても，先行研 究16,17)で行われているような所定の手続きにしたが って予測モデルを構築することで，実用場面におい ても有効な推定規則を見出すことが可能だと考えら れる.

\section{手続き}

ロジスティック回帰分析 犯人属性ごとに犯罪手 口による予測を検討するため，犯人属性（17変数）
を目的変数，犯罪手口（50変数）を説明変数とした ロジスティック回帰分析を行った。ロジスティック 回帰分析は，予測したい変数（目的変数）が離散変 数のときに用いられる手法であり，分析で導かれる モデル（回帰式）を用いて目的変数の判別を行うこ とができる.なお，目的変数には欠損值を含むもの があるため, 各分析は, 目的变数が欠損值であるサ ンプルを除外して行った.

変数選択 説明変数が複数の場合, 目的变数の予 測に重要な変数を選別するため，変数選択を行う。 変数選択の基準としては説明変数ごとに算出される $p$ 值 (有意確率) がよく, 変数選択の方法としては 
変数の数が少ないときに変数減増法, 多いときに変 数増減法を用いるとよいとされている23). したがっ て本研究では, モデルに使用する説明変数を変数増 減法によって選択し， $p$ 值の 5\%を基準として変数 の投入と除去を行った.

多重共線性の確認 ロジスティック回帰分析を行 う際には, 説明变数間に強い相関 (多重共線性) が あると回帰係数の標準誤差が大きくなり, 推定值が 不安定になる場合がある24)。太郎丸は, 多重共線性 の問題を避ける方法として, 説明变数間の相関係数 が0.7未満であることを一つの目安として提示して いる ${ }^{24)}$. しかし, 個々の变数の組み合わせで 0.7 未 満の相関係数であっても, 多重共線性が成り立つ場 合がある. 内田は, 多重共線性が生じているモデル の現象として, 目的变数と説明変数が正の相関関係 にあるにもかかわらず偏回帰係数の符号が負となる ケース（符号逆転）をあげている23).したがって， 目的变数と説明変数の相関係数の符号々偏回帰係数 の符号が一致しているかを確認することで, 作成し たモデルについても多重共線性を確認することがで きる. 本研究では, 多重共線性の問題を避けるた め, 説明変数間の相関係数を算出したところ, 相関 係数は全ての説明変数の組み合わせで 0.7 未満であ り, 特に相関が高い変数の組み合わせは無いと判断 して, 全ての説明変数を分析に使用した. さらに作 成されたモデルについても多重共線性を確認するた め, 目的変数々説明変数の相関係数の符号々偏回帰 係数の符号が一致しているかを確認し, 一致してい ない説明変数があった場合は, その变数と最も相関 係数の高い説明変数との二つの变数の中で, 目的変 数との相関係数が低い方の变数を除外して再分析を 実施した。

モデルの有用性の評価 モデルの有用性は, 適合 度と判別的中率の二つの指標による評価が可能であ る.したがって本研究では, 以下の二つの基準を満 たすモデルについて詳細な評価を行った.

1. 適合度 モデルの適合度の評価には, 基準值 が Swets ${ }^{25)}$ により示されているROC 曲線（receiver operating characteristic curve) が有効な指標の一つ であり, 他の罪種を対象とした研究でも用いられて いる16,17)。 ROC曲線は, 真陽性率 (true positive rates：陽性群の中で正しく陽性群に分類された割 合）と偽陽性率（false positive rates：陰性群の中 で誤って陽性群に分類された割合）に基づいて作図 される．このとき算出できるROC曲線下の面積 (AUC: area under the ROC curve) は全ての閾值の 判別的中率を集約してモデルの適合度を評価するこ とができ，モデル間の適合度の比較も選択した閾值 によるバイアスの影響を受けずに行うことができ る26). Swets は, AUCの評価基準として，0.50〜 0.70を低いレベル，0.70０.90を中程度のレベル， 0.90〜1.00を高いレベルとしている25). モデルの評 価を行う際に，モデルの学習データとテスト用の データを分けて検証を行う方法として, 交差検証法 がある27). 交差検証法の一つである $n$ 重交差検証 法（ $n$-fold cross validation）では, データを $n$ 等分 してそのうち一つをテスト用とし, 残りの $n-1$ 個 を学習用として, $n$ 回の学習とテストを行う方法で ある. Fujita et al. ${ }^{17)}$ は, 殺人犯の犯人属性を予測 する研究で ROC 曲線を作成する手続きに10重交差 検証法（10-fold cross validation）を採用し，すべ てのデータに基づいてステップワイズ法で説明変数 を選択した後, 学習用データから各説明変数の回帰 係数を算出してモデル構築を行い，そのモデルをテ スト用データに適用して予測值を得る手続きを繰り 返すことで，すべてのサンプルについて交差妥当化 した予測值を算出し, ROC 曲線を作成している. 本研究では Fujita et al. の方法にしたがい, 選択し た説明変数の組合せに対して10重交差検証法を用い て ROC 曲線を作成し，AUC が中程度 $(0.70 \sim 0.90)$ 以上であることをモデルの有用性に関する一つ目の 基準とした。

2. 判別的中率 モデルの有用性を評価する際に は，適合度だけでなく判別的中率も重要であり，も ともと比率が多い側のカテゴリが占める割合（予測 の事前確率）を超える精度でないと意味がない23).

Santtila et al. は，犯人属性を予測する回帰モデル の有効性を評価する基準として, 回帰モデルの判別 的中率 (correct classification rate) が予測の事前確 率（best-guess rate）に比べて大きいことを採用し ていることから ${ }^{14)}$, 本研究に抢いても, 判別的中率 が予測の事前確率よりも大きいことを, モデルの有 
用性に関する二つ目の基準とした．目的変数の判定 基準には，各モデルについて作成した ROC 曲線に おける真陽性率と偽陽性率の差が最大となる閾值 (Youden index) $)^{26)}$ を採用し，10重交差検証法によ って算出したサンプルの予測值に適用することで, 判別的中率を算出した.

有用性の高いモデルに含まれる説明変数の評価 作成されたモデルに含まれる説明変数の評価には, 偏回帰係数，Wald 検定量，オッズ比を用いた。偏 回帰係数は，各説明变数の目的变数に対する影響の 強さと方向性を示している. Wald 検定量は偏回帰 係数を標準誤差で除したものを二乗した值であり, $\chi^{2}$ 分布に従い, 説明変数の $p$ 值を求妨ときに使 用される.オッズ比は各説明変数が 1 単位増加した 時に生じる目的变数のオッズ（目的变数の事象が生
起する確率 $(P)$ の生起しない確率 $(1-P)$ に対 する比）の変化を表す。

\section{結 果}

17の目的変数について作成されたモデルのうち, AUC が 0.70 以上だったモデルの数が 6, 判別的中 率が事前確率よりも大きかったモデルの数が 9 であ り, 両方の基準を満たしたのは, 犯行時年齢, 共犯 形態, 空き巣の犯罪経歴, 忍込みの犯罪経歴の 4 つ のモデルだった（Table 3). 基準を満たしたモデル の AUC はすべて中程度のレベル（0.70０.85）で あり, 事前確率からの改善は犯行時年齢 $(16.7 \%)$, 空き巣の犯罪経歴 (14.8\%), 忍込久の犯罪経歴 $(11.8 \%)$ ，共犯形態 $(1.3 \%)$ の順に大きかった. 基準を満たしたモデルの詳細を Table 4 に示す。各

Table 3 The usefulness of the models.

\begin{tabular}{|c|c|c|c|c|c|c|}
\hline Offender characteristic & Most probable category & $N$ & $\begin{array}{c}\text { Prior } \\
\text { probability }\end{array}$ & $\begin{array}{c}\text { Prediction } \\
\text { accuracy }\end{array}$ & AUC & $\begin{array}{l}95 \% \mathrm{CI} \\
\text { for AUC }\end{array}$ \\
\hline $\begin{array}{l}\text { Offender age at the time of the } \\
\text { first offense }\end{array}$ & Less than 36 & 305 & $50.2 \%$ & $66.9 \%$ & 0.70 & $0.65-0.75$ \\
\hline Sex & Male & 303 & $96.4 \%$ & $64.4 \%$ & 0.53 & $0.38-0.67$ \\
\hline Presence of co-offender & Without & 305 & $80.0 \%$ & $81.3 \%$ & 0.85 & $0.79-0.90$ \\
\hline Employment status & Unemployed & 305 & $69.5 \%$ & $72.8 \%$ & 0.59 & $0.55-0.64$ \\
\hline Marital status & Unmarried & 305 & $61.3 \%$ & $60.0 \%$ & 0.54 & $0.51-0.57$ \\
\hline Residential status & With a permanent address & 301 & $66.1 \%$ & $72.8 \%$ & 0.63 & $0.58-0.67$ \\
\hline Education & $\begin{array}{l}\text { Some high school, junior high } \\
\text { school graduation, or less }\end{array}$ & 288 & $63.9 \%$ & $\%$ & 0.55 & $0.50-0.60$ \\
\hline Mental problem & Without & 305 & $95.4 \%$ & $75.4 \%$ & 0.68 & $0.57-0.79$ \\
\hline Familiarity with the victim & Without & 286 & $92.7 \%$ & $84.6 \%$ & 0.65 & $0.53-0.78$ \\
\hline Familiarity with the area & With & 286 & $71.7 \%$ & $65.0 \%$ & 0.63 & $0.57-0.69$ \\
\hline $\begin{array}{l}\text { Lack of familiarity with the vic- } \\
\text { tim and the area }\end{array}$ & Without & 286 & $79.0 \%$ & $65.7 \%$ & $\mathbf{0 . 8 0}$ & $0.74-0.85$ \\
\hline $\begin{array}{l}\text { Criminal history of house burg- } \\
\text { laries (stealing in one's absence) }\end{array}$ & Without & 305 & $50.2 \%$ & $64.9 \%$ & 0.70 & $0.64-0.75$ \\
\hline $\begin{array}{l}\text { Criminal history of house burg- } \\
\text { laries (stealing late at night) }\end{array}$ & Without & 305 & $61.6 \%$ & $73.4 \%$ & 0.74 & $0.69-0.80$ \\
\hline $\begin{array}{l}\text { Criminal history of house burgla- } \\
\text { ries (stealing while one's at home) }\end{array}$ & Without & 305 & $80.7 \%$ & $74.1 \%$ & 0.72 & $0.65-0.79$ \\
\hline $\begin{array}{l}\text { Criminal history of burglaries } \\
\text { other than house }\end{array}$ & Without & 305 & $57.7 \%$ & $66.2 \%$ & 0.66 & $0.60-0.71$ \\
\hline $\begin{array}{l}\text { Criminal history of theft through } \\
\text { non-breaking and non-entering }\end{array}$ & With & 305 & $58.0 \%$ & $67.2 \%$ & 0.67 & $0.63-0.72$ \\
\hline Criminal history other than theft & Without & 305 & $66.6 \%$ & $63.9 \%$ & 0.63 & $0.58-0.67$ \\
\hline
\end{tabular}

Prior probability is the percentage of the most probable category in each offender characteristics.

$\mathrm{AUC}=$ area under the ROC curve.

Highlighted in bold is the values that fulfilled a criterion. 
Table 4 Selected models as useful.

$\begin{array}{lllll}\text { Variable } & B & \text { SE } & \text { Wald } & \operatorname{Exp}(B)\end{array}$

Offender age at the time of the first offense (36 or more $=152$, Less than $36=153, R^{2}=0.21$ )

$\begin{array}{lrlcl}\text { Coupons and tickets } & 1.01 & 0.30 & 11.65^{* *} & 2.74 \\ \text { Daytime } & 0.60 & 0.27 & 4.85^{*} & 1.83 \\ \text { Slightly search } & 0.54 & 0.25 & 4.57^{*} & 1.72 \\ \text { Exit open } & -1.45 & 0.50 & 8.38^{* *} & 0.23 \\ \text { Toys and games } & -2.02 & 0.38 & 29.04^{* *} & 0.13\end{array}$

Presence of co-offender (With $=61$, Without $=244$, $\left.R^{2}=0.46\right)$

$\begin{array}{lrllr}\text { On alley } & 2.47 & 0.86 & 8.19^{* *} & 11.86 \\ \text { Toys and games } & 1.35 & 0.45 & 9.14^{* *} & 3.86 \\ \text { Spree } & 1.23 & 0.41 & 9.28^{* *} & 3.44 \\ \text { Jewellery } & 1.02 & 0.40 & 6.51^{*} & 2.78 \\ \text { Untidy search } & 0.99 & 0.40 & 6.04^{*} & 2.69 \\ \text { Daytime } & -0.86 & 0.39 & 4.90^{*} & 0.42 \\ \text { Entry through a un- } & -1.18 & 0.41 & 8.18^{* *} & 0.31 \\ \text { locked entrance } & & & & \\ \text { Exit closed } & -1.27 & 0.39 & 10.79^{* *} & 0.28 \\ \text { Lingerie } & -2.17 & 0.73 & 8.73^{* *} & 0.11 \\ \text { Small electrical items } & -3.25 & 1.12 & 8.37^{* *} & 0.04\end{array}$

Criminal history of house burglaries (stealing in one's absence) $\left(\right.$ With $=152$, Without $=153, R^{2}=0.23$ )

$\begin{array}{lrlcl}\text { Use of stolen bicycles } & 1.17 & 0.42 & 7.53^{* *} & 3.21 \\ \text { Near station } & 1.15 & 0.47 & 6.06^{*} & 3.17 \\ \text { Cash with wallet } & 1.10 & 0.28 & 15.32^{* *} & 3.00 \\ \text { stolen } & 0.99 & 0.40 & 6.18^{*} & 2.68 \\ \text { On alley } & 0.76 & 0.29 & 6.86^{* *} & 2.14 \\ \text { Coupons and tickets } & -0.62 & 0.29 & 4.43^{*} & 0.54 \\ \text { Late at night } & -0.96 & 0.28 & 12.20^{* *} & 0.38 \\ \text { One's shoes off } & -1.26 & 0.55 & 5.15^{*} & 0.28\end{array}$

Criminal history of house burglaries (stealing late at night $)\left(\right.$ With $=117$, Without $\left.=188, R^{2}=0.29\right)$

Small electrical items $\quad \begin{array}{lllll}1.11 & 0.51 & 4.75^{*} & 3.04\end{array}$

$\begin{array}{lllll}\text { Late at night } & 1.09 & 0.30 & 13.09^{* *} & 2.97\end{array}$

$\begin{array}{lllll}\text { Spree } & 1.02 & 0.28 & 13.00^{* *} & 2.77\end{array}$

$\begin{array}{lllll}\text { Watches } & 0.90 & 0.32 & 7.85^{* *} & 2.46\end{array}$

$\begin{array}{lllll}\text { Took money out of } \quad 0.70 & 0.29 & 5.83 * & 2.02\end{array}$ wallet

$\begin{array}{lllll}\text { Evening } & -0.71 & 0.31 & 5.44^{*} & 0.49 \\ \text { Toys and games } & -1.13 & 0.39 & 8.41^{* *} & 0.32\end{array}$

$\begin{array}{lllll}\text { Exit open } & -1.55 & 0.57 & 7.43^{* *} & 0.21\end{array}$

$\mathrm{SE}=$ Standard error; $R^{2}=$ Nagelkerke's $R^{2}$. ${ }^{* *} p<0.01,{ }^{*} p<0.05$.

モデルの説明变数の構成は次のとおりである.

\section{犯行時年齢}

犯人の年齢が 36 歳以上である可能性は，「朝〜午
後」に犯行に及び，「浅い物色」で「金券類」を盗 むといった行動が認められる場合に高くなり，36歳 未満の可能性は，「玩具類」を窃取，「逃走口を開放」 するといった行動が認められる場合に高くなるモデ ルが作成された。

\section{共犯形態}

複数犯である可能性は, 「裏通り・路地」で「連 続犯行」に及び，現場を「散乱物色」，「宝石・指輪 類」や「玩具類」を盗むといった行動が認められる 場合に高くなり，単独犯の可能性は，「朝〜午後」 に「無締り箇所から侵入」して「小型電子機器」や 「女性用下着」を窃取，逃走時に「逃走口を閉める」 といった行動が認められる場合に高くなるモデルが 作成された。

\section{空き巣の犯罪経歴}

空き巣の犯罪経歴を持っている可能性は，「駅付 近」の「裏通り・路地」で犯行に及び，「金券類」 を盗み，現金を「財布・封筒ごと窃取」して「窃取 した自転車を使用」するといった行動が認められる 場合に高くなり，空き巣の犯罪経歴を持っていない 可能性は，「深夜〜未明」に犯行（忍込み）に及び， 「靴を脱いで侵入」して「逃走口を開放」するとい った行動が認められる場合に高くなるモデルが作成 された.

\section{忍込みの犯罪経歴}

忍込みの犯罪経歴を持っている可能性は，「深夜 〜未明」に「連続犯行」に及び，「時計」や「小型 電子機器」を盗み，現金を「財布・封筒から抜き取 り」窃取するといった行動が認められる場合に高 く，忍込みの犯罪経歴を持っていない可能性は， 「宵〜中夜」に犯行に及び，「玩具類」を窃取，「逃 走口を開放」するといった行動が認められる場合に 高くなるモデルが作成された。

\section{考 察}

有用性の基準を満たしたモデルの解釈

適合度，判別的中率の両基準を満たした 4 つのモ デルは，犯人属性を少数の関連が深い犯罪手口から 予測できる可能性を示しており，今後の捜査活動に 応用しやすいモデルだと言える。

高い判別的中率を得るため变数を 2 值化した「犯 
行時年齢」では, 寄与率は低いものの $\left(R^{2}=0.21\right)$, モデルの適合率は中程度のレベル $(\mathrm{AUC}=0.70)$ であり，年齢の予測ができる可能性が示された。し かし，今後さらに細分化した年齢の予測を行うに は, Snook ${ }^{15)}$ が年齢との関連を指摘している犯行移 動距離などの犯罪手口以外の変数も使用して, 精度 の向上をはかる必要があるだろう。モデルを構成す る変数についてみると，「玩具類」が年齢の低さを 説明する変数として含まれていた．高村と徳山5) は，「玩具類」が少年の被疑者を強く示唆する目的 物であることを示しており，本研究で得られた結果 と一致する，窃盗犯捜査研究会 ${ }^{11}$ は，常習窃盗犯は 楽に多くの現金を得られる物（換金が容易，小型， 高価）を好む傾向があることを指摘しており，そう した目的物の一つとして，特に足がつきにくい「金 券類」が考えられる. 加えて, 高村と徳山占は, 窃 盗経験の多少が犯人の年齢と強く結び付いているこ とを示唆している。したがって，常習窃盗犯に比較 的年齢の高い被疑者が多いことから，比較的年齢の 高い被疑者に「金券類」が選択されやすいという傾 向が見出された可能性がある. また，常習究盗犯の 物色特徵として現金や貴金属などの特定の物に目標 を定める傾向が指摘されていることから ${ }^{11)}$ ，目的物 の収納場所へ直行し，他を物色しないために「浅い 物色」となることが考えられる.さらに常習性にし たがって解釈すれば，「朝〜午後」の犯行は大部分 が空き巣であることから，空き巣を行う犯人には常 習犯が多く，窃盗経験の少ない被疑者は「逃走口を 開放」したまま逃走することが多いのかもしれな い.

「共犯形態」では，「犯行時年齢」のモデルにも含 まれていた「朝〜午後」と「玩具類」が含まれてお り, 先行研究で若い犯人には複数犯が多いこ と28,29)，初犯者に複数犯での犯行が多いこと年, が 指摘されていることからも，複数犯で行われる犯行 には初犯の若年層が一定数含まれていると考えられ る.しかし，人通りの少ない「裏通り・路地」で 「連続犯行」に及び，「散乱物色」をして「宝石・指 輪類」を盗むと言う手口から，複数犯の共通した傾 向として常習性が低いとは言えない。「無締り箇所 から侵入」，「逃走口を閉める」といった手口が少な
いことから, 複数犯の場合は比較的大胆な手口で窃 盗を行う組織穷盗の犯人が含まれていることが影響 していると考えられる. また, 「女性用下着」が単 独犯である可能性を高めることは, 高村と徳山が収 集した68名（うち侵入盗は16名）の色情盗がすべて 単独犯であったことと一致しており4), 性的動機に よる侵入窃盗犯の多くは単独犯だと言える.さら に, 「小型電子機器」については, 複数犯に比べて より物色の効率化や犯行の発覚に配慮した手口との 関連が強い「忍込反の犯罪経歴」をもつ可能性が高 くなる変数であり，複数犯には選択されにくい目的 物である可能性が考えられる.

犯罪経歴に関するモデルについても，「犯行時年 齢」のモデルに含まれる変数が「共犯形態」と同様 に含まれていた．「空き巣の犯罪経歴」のモデルに は, 経歴があることを示す説明変数として年齢が高 いことを示す「金券類」が，経歴がないことを示す 説明变数として年齢が低いことを示す「逃走口を開 放」が含まれていた。また，「忍込反の犯罪経歴」 のモデルには，経歴がないことを示す説明变数とし て年齢が低いことを示す「玩具類」，「逃走口を開放」 が含まれていた。 今回使用したデータから $t$ 検定を 行った結果, 空き巣 $(t(303)=6.20, p<.001)$ と 忍込久 $(t(303)=6.61, p<.001)$ の犯罪経歴の有 無について年齢との関連が確認されたことからも， 2 種類の犯罪経歴はともに被疑者の年齢と関連があ ることが確認された. 今回従属変数として使用した 年齢々犯罪経歴との間の相関比は,「犯行時年齢」

と「空き巣の犯罪経歴」で $r=.34$,「犯行時年齢」

と「忍込みの犯罪経歴」で $r=.35$ であった.

犯罪経歴については, 空き巣, 忍込み, 居空きと いった犯罪の定義と関連する犯行時間帯に基づいて 解釈することも重要である. 本研究の結果からは, 「深夜〜未明」の犯行が含まれるケースで「空き巣 の犯罪経歴」をもつ可能性が低くなることおよび 「忍込久の犯罪経歴」をもつ可能性が高くなること が示されるとともに，「宵〜中夜」の犯行が含まれ るケースで「忍込反の犯罪経歴」をもつ可能性が低 くなることが示された.「深夜〜未明」の犯行は定 義上忍込みであり，「宵〜中夜」の犯行の大部分は 空き巣または居空きであることから, 過去に忍込み 
の犯罪経歴がある被疑者はその後空き巣や居空きを 行う場合は少なく, 忍込みを手口として選択しやす いこと, さらに, 過去に空き巣の犯罪経歴がある被 疑者はその後忍込反を行う場合は少なく, 空き巣や 居空きを手口として選択する場合が多いことを示し ている. Yokota and Canter ${ }^{31}$ は, 日本の15種類の 窃盗について犯人ごとの全犯行件数に対する犯行の 生起頻度をもとにしたテーマ分類と手口の專門化に ついての検討を行い, ほとんどの侵入窃盗犯が「住 居」か「商業施設」に専門化していき，同じ「住居」 テーマに属する中でも, 忍込みが他の $2 つ （$ 空き 巣, 居空き）とは区別される可能性があることを指 摘している. 本研究では被疑者の検挙事件と犯罪経 歴との関係ではあるが，手口の専門化が同じ「住居」 テーマの中でも起きることが示された.

犯行時間帯の他に犯罪経歴に関するモデルに含ま れる説明変数については, 前述の「犯行時年齢」と の関連以外にも，それぞれ突盗経験の多少を背景と する変数として解釈することができる．「空き巣の 犯罪経歴」に関しては，経歴をもつことを予測する 「駅付近」,「董通り・路地」, 抢よび経歴をもたない ことを予測する「逃走口を開放」について，逃走が 容易かつ犯行前後の行動が人目につかない場所11)で 犯行に及び，犯行時に発覚しないように努力する ${ }^{30)}$ 常習窃盗犯の傾向に関連する手口だと考えられる。

また，「金券類」を窃取する場合が多いことは，前 述した楽に多くの現金を得られるものを好む傾向 ${ }^{11}$ を反映していると言える。「窃取した自転車を使用」 する場合が多い理由としては，逮捕のリスクを減ら すために，単なる交通手段として自転車を使用する 際に自己が所有する自転車の使用を避けている可能 性とともに，空き巣は被害者が不在時に犯行を行う ため忍込みに比べて電気製品などの大きな物品を窃 取しやすいことから，铅取品を搬出する手段として も，使い捨てが容易なものとして選択されやすい可 能性が考えられる.「財布・封筒ごと窃取」する場 合が多いことについては, 滞在時間を減らすことで 現場で発覚するリスクを低減できるとともに，日中 の犯行が多いため, 逃走中に不審者として警察官に 呼び止められることで犯行が発覚する可能性も低い ことから, 空き巣では財布や現金以外の中身も目的
物の一つとしてとらえられることが多い可能性があ る、「靴を脱いで侵入」する場合が少ないことにつ いては，現場に土足の足跡を残す可能性に対して， 犯行中に被害者が州宅するなどして犯行が発覚した 際に，靴を遺留することなくすぐに逃走できること を優先した合理的な選択と考えることができる.

「忍込久の犯罪経歴」に関しては, 経歴をもつこと を予測する「連続犯行」は, 窃盗経験の多さを示す 変数の一つであり5), 「財布・封筒から抜き取り」, $「$ 時計」, 携帯音楽プレーヤーや携帯情報端末 （PDA）を含む「小型電子機器」は，いずれも常習 窃盗犯が楽に多くの現金を得られるものを好む傾 向11)関連する手口である. また，経歴をもたない ことを予測する「玩具類」は, 空き巣とは異なり, 忍込久では被害者が就寝中に犯行を行うことから， 犯行時に家人に気付かれないようにする必要がある ため, 物色の効率化や逃走時の身軽さを考慮した場 合に目的物とはなりにくいのかもしれない。さら に,「空き巣の犯罪経歴」および「忍込みの犯罪経 歴」をもたないことを予測する「逃走口を開放」は， 「犯行時年齢」のモデルにおける解釈と同様に, 窃 盗経験の少ない被疑者が行いやすい行動だ考えら れる. 以上のように，「空き巣の犯罪経歴」と「忍 込反の犯罪経歴」ではいずれも铂盗経験の多少を反 映した手口がモデルに多く含まれていることから， 空き巣, 忍込反ともに常習性が増すことで, より効 率的で犯行の発覚と検挙されるリスクに配慮する方 向へと手口が洗練化していくと考えられる. 一方 で，「空き巣の犯罪経歴」を予測するモデルと「忍 込反の犯罪経歴」を予測するモデルには, 互いに異 なる説明変数が多く含まれていた，これは，空き巣 と忍込みの犯行形態の違いを反映した結果と考えら れ，同じ窃盗経験が豊富な被疑者であっても，その 経験が空き巣と忍込みのどちらが主となるものかに よって異なる手口の専門化が生じて抢り, 犯罪経歴 の予測モデルに反映されたと考えられる.

Santtila et al. の研究では, 85の犯罪手口に主成 分分析を適用して抽出した侵入窃盗における14の類 型のうち, 有意な説明変数として回帰モデルに含ま れる類型の数が，年齢（11類型）に抢いて他の犯人 属性（1５類型）に比べて多く, 類型ごとの考察 
では，犯人の年齢と窃盗経験に基づく解釈が広く用 いられていた ${ }^{14)}$. また，Santtila et al. は結果全体 に関する考察として，抽出された侵入窃盗の類型 が，プロフェッショナルから機会犯までの連続体上 のものとして考えることができると述べている．本 研究においても，有用性が高いモデルに含まれる犯 罪手口の傾向として, Santtila et al. と同様に窃盗 経験と年齢に関連する変数が多く含まれていたこと は興味深い。高村と徳山による研究5)において，住 居対象侵入窃盗犯に対する数量化正類で第 I 軸とし て㲾盗経験が抽出されたこと, 穷盗経験の軸に基づ いて犯人属性を解釈した際に年齢的分析变数が大き く反映されていたことからも，日本の住居対象侵入 窃盗犯に抢ける犯人属性と犯罪手口に共通する背景 要因として窃盗経験と年齢が重要な役割を果たして おり，予測対象の犯人属性と同じ背景要因を有する 犯罪手口が抽出されることによって，犯人属性を予 測するモデルが作成されたと考えられる.

\section{成果の応用之展望}

本研究で有用性の基準を満たしたモデルは，分析 対象事件の情報をモデル式にそのまま適用して予測 を行うことが可能である. しかし，犯罪捜査への活 用を目的とした犯人像推定に応用寸る際は，分析対 象事件と同地域のデータを用いて，モデルの検証や 新たなモデルの作成をすることが望ましい。これら の手続きを行い, 本研究のモデルと比較すること で，その地域の住居対象侵入容盗犯の特徵的な手口 を把握できることも期待される.

また，本研究は被疑者が検挙された事件のデータ に基づいており，実用場面においては検挙されにく い犯人による事件に対してモデルが適用されるケー スが研究場面に比べて多くなると考えられる．検挙 されにくい犯人の場合，窃盗では逮捕のリスクを軽 減するための方略の洗練化が進んでいる可能性が高 い.しかし，今回のデータでも常習穷盗犯が一定数 含まれていることから，検挙事件から構築されたモ デルによる予測は有効だと考えられる．ただし，安 定した応用に結びつけるためには，長期間に渡って 多数の犯行に及んでから検挙された被疑者のデータ を収集してモデルを適用するなど，今後の検証が必 要だろう。
本研究で設定した基準を満たすモデルが作成され なかった犯人属性については，二つの理由が考えら れる。一つ目は, 犯人属性と関連がある犯罪手口が 少ないことである。これは, 窃盗経験や年齢との関 連が小さい犯人属性であることが背景として考えら れ，そうした犯人属性に関する犯人像推定の潜在的 な困難さを示しているとも言える。しかし，それら の犯人属性についても, 窃盗経験や年齢以外の背景 要因が存在すれば，同様の背景を持つ説明变数を用 いることで予測できる可能性がある。したがって， この課題を克服する方法としては, 本研究で説明変 数として使用していない犯罪手口や, 犯行の地理 的・時間的な要素を検討することが考えられる．こ の方法には，より多くの説明変数が必要となるもの の, 予測できる犯人属性を増やすことができる可能 性がある. 有用なモデルが作成されない二つ目の理 由としては, 今回検討した犯人属性には出現頻度の 低いカテゴリ（e.g. 女性, 精神的問題あり, 被害者 に関する知識あり）が多かったことがあげられる. たとえば，出現頻度が最も低かった「女性」では， サンプルは11名であり，このようなごく少数のデー タから良好な予測モデルを構築することは難しい。 したがって，こうした犯人属性についてより適切な 検証を行うためには, 出現頻度の低いカテゴリに該 当する被疑者に範囲を限定してデータを収集し，そ の特徵を分析するなど, 本研究とは異なる方法での 検討を行うことで，予測に有効な变数を見出すこと が期待される.

\section{謝 辞}

本研究を行うにあたり, 滋賀県警察の倉石宏樹氏 には分析手法について貴重な御助言をいただき，科 学警察研究所の渡邊和美先生, 法政大学の越智啓太 教授，福島県警察の杉山翠氏には原稿に対して多く の御助言をいただきました。この場を借りて深く感 謝いたします。

\section{文 献}

1）渡辺昭一，犯罪者プロファイリング一犯罪を 科学する警察の情報分析技術. 角川書店, 東 京, 2005 . 
2) Canter, D. and Heritage, R., A multivariate model of sexual offence behavior: Developments in 'offender profiling'. J Forensic Psychiatr, 1, 185 -212. 1990.

3) Douglas, J. E., Ressler, R. K., Burgess, A. W., and Hartman, C. R., Criminal profiling from crime scene analysis. Behav. Sci. Law, 4, 401-421. 1986.

4）高村 茂, 徳山孝之, 民家対象窃盗犯の犯人 特性に関する基礎的研究. 犯罪心理学研究, 41, 1-14. 2003.

5）高村 茂, 徳山孝之, 多変量解析を用いた犯 罪者プロファイリング研究一侵入窃盗犯の類型 化に着目して一. 犯罪心理学研究, 43, 29-41. 2006.

6) 渡邊和美, 田村雅幸, 戦後 50 年間におけるバ ラバラ殺人事件の形態分析. 科学警察研究所報 告 (防犯少年編)，39，47-55. 1998a.

7）渡邊和美, 田村雅幸, バラバラ殺人事件の犯 人像分析. 科学警察研究所報告 (防犯少年編), 39, 1-17. 1998b.

8）渡邊和美, 田村雅幸, 13歳未満の少女を対象 とした強茹事件の犯人像分析 1 . 加害者の特徽 と犯歴に関する分析 科学警察研究所報告（防 犯少年編)，40,67-81. 1999.

9）渡邊和美, 田村雅幸, 13歳未満の少女を対象 とした強姦事件の犯人像分析 2 . 加害者. 被害 者間の面識関係に関する分析. 科学警察研究所 報告（防犯少年編），41，58-66. 2001.

10）横田賀英子，犯罪手口を用いた優先順位によ る被疑者検索. 渡辺昭一（編）捜査心理学. pp. 41-50, 北大路書房, 京都, 2004.

11）窃盗犯捜査研究会, 窃盗犯捜査の実際. 立花 書房，東京， 1985.

12）岩見広一, カンターの犯罪者プロファイリン グ手法. 渡邊和美, 高村 茂, 桐生正幸（編著） 犯罪者プロファイリング入門一行動科学と情報 分析からの多様なアプローチ. pp. 61-68, 北大 路書房, 京都, 2006.

13）財津 亘, 犯人像推定におけるべイズ方式へ の展開. 犯罪心理学研究，47, 75-87. 2009.
14) Santtila, P., Ritvanen, A., and Mokros, A., Predicting burglar characteristics from crime scene behavior. Int. J. Pol. Sci. Manag, 6, 136154. 2004.

15) Snook, B., Individual differences in distance traveled by serial burglars. J. Invest. Psychol. Offender Profiling, 1, 53-66. 2004.

16) Yokota, K., Fujita, G., Watanabe, K., Yoshimoto, K. and Wachi, T., Application of the behavioral investigative support system for profiling perpetrators of serial sexual assaults. Behav. Sci. Law, 25, 841-856. 2007.

17) Fujita, G., Watanabe, K., Yokota, K., Kuraishi, H., Suzuki, M., Wachi, T., and Otsuka, Y., Multivariate models for behavioral offender profiling of Japanese homicide. Crim. Justice Behav, 40, 214-227. 2013.

18）横田賀英子，渡辺昭一，犯罪手口の反復性に 関する分析. 日本鑑識科学技術学会誌，3,4955. 1998.

19）三本照美，地理的プロファイリング。渡邊和 美, 高村 茂, 桐生正幸 (編著) 犯罪者プロフ アイリング入門一行動科学と情報分析からの多 様なアプローチ. pp. 72-82, 北大路書房, 京 都, 2006.

20）財津 亘，強姦犯の犯罪深度を基にしたべィ ジアンネットワークモデルによる犯行時期に関 する予測. 日本法科学技術学会誌, 13, 133142. 2008.

21) Alison, L. J., Snook, B., and Stein, K. L., Unobtrusive measurement: Using police information for forensic research. Qual. Res, 1, 241-254. 2001.

22) Canter, D. and Alison, L. J., Converting evidence into data: The use of law enforcement archives as unobtrusive measurement. Qual. Rep, 8, 151-176. 2003.

23）内田 治, SPSS によるロジスティック回帰 分析. オーム社, 東京, 2011.

24）太郎丸博, 人文・社会科学のためのカテゴリ カル・データ解析入門. ナカニシヤ出版, 京 
都, 2005.

25) Swets, J. A., Measuring the accuracy of diagnostic systems. Science, 240, 1285-1293. 1988.

26) Krzanowski, W. J. and Hand, D. J., ROC curves for continuous data. CRC Press, Boca Raton, 2009.

27）金 明哲， R によるデータサイエンス．森北 出版, 東京, 2007 .

28) Eskridge, C. W., Prediction of burglary: A research note. J. Crim. Justice, 11, 67-75, 1983.
29) Reiss, A. J. and Farrington, D. P., Advancing knowledge about co-offending: Results from a prospective longitudinal survey of London males. J. Crim. Law Criminol, 82, 360-395, 1991.

30）高橋良彰, 犯罪社会心理学. 令文社, 東京, 1993.

31) Yokota, K. and Canter, D., Burglars' specialisation: development of a thematic approach in investigative psychology. Behaviormetrika, 31, 153167. 2004. 